\title{
Spectrometric and Voltammetric Analysis of Urease - Nickel Nanoelectrode as an Electrochemical Sensor
}

Jaromir Hubalek ${ }^{1}$, Jan Hradecky ${ }^{2}$, Vojtech Adam ${ }^{2,3}$, Olga Krystofova ${ }^{2}$, Dalibor Huska ${ }^{2}$, Michal Masarik ${ }^{4}$, Libuse Trnkova ${ }^{5}$, Ales Horna ${ }^{6}$, Katerina Klosova ${ }^{1}$, Martin Adamek ${ }^{1}$, Josef Zehnalek $^{2}$ and Rene Kizek ${ }^{1, *}$

${ }^{1}$ Department of Microelectronics, Faculty of Electrical Engineering and Communication, Brno University of Technology, Udolni 53, CZ-602 00 Brno, Czech Republic

${ }^{2}$ Department of Chemistry and Biochemistry, and ${ }^{3}$ Department of Animal Nutrition and Forage Production, Faculty of Agronomy, Mendel University of Agriculture and Forestry, Zemedelska 1, CZ61300 Brno, Czech Republic

${ }^{4}$ Department of Pathological Physiology, Faculty of Medicine, Masaryk University, Komenskeho namesti 2, CZ-662 43 Brno, Czech Republic

${ }^{5}$ Department of Chemistry, Faculty of Science, Masaryk University, Kotlarska 2, CZ-611 37 Brno, Czech Republic

${ }^{6}$ Department of Food Engineering, Faculty of Technology, Tomas Bata University, T.G. Masaryka 275, CZ-762 72 Zlin, Czech Republic

* Author to whom correspondence should be addressed; E-mail: kizek@ sci.muni.cz

Received: 3 July 2007 / Accepted: 13 July 2007 / Published: 16 July 2007

\begin{abstract}
Urease is the enzyme catalyzing the hydrolysis of urea into carbon dioxide and ammonia. This enzyme is substrate-specific, which means that the enzyme catalyzes the hydrolysis of urea only. This feature is a basic diagnostic criterion used in the determination of many bacteria species. Most of the methods utilized for detection of urease are based on analysis of its enzyme activity - the hydrolysis of urea. The aim of this work was to detect urease indirectly by spectrometric method and directly by voltammetric methods. As spectrometric method we used is called indophenol assay. The sensitivity of detection itself is not sufficient to analyse the samples without pre-concentration steps. Therefore we utilized adsorptive transfer stripping technique coupled with differential
\end{abstract}


pulse voltammetry to detect urease. The influence of accumulation time, $\mathrm{pH}$ of supporting electrolyte and concentration of urease on the enzyme peak height was investigated. Under the optimized experimental conditions $(0.2 \mathrm{M}$ acetate buffer $\mathrm{pH} 4.6$ and accumulation time of $120 \mathrm{~s}$ ) the detection limit of urease evaluated as $3 \mathrm{~S} / \mathrm{N}$ was $200 \mathrm{ng} / \mathrm{ml}$. The activity of urease enzyme depends on the presence of nickel. Thus the influence of nickel(II) ions on electrochemical response of the enzyme was studied. Based on the results obtained the interaction of nickel(II) ions and urease can be determined using electrochemical methods. Therefore we prepared Ni nanoelectrodes to measure urease. The Ni nanoelectrodes was analysed after the template dissolution by scanning electron microscopy. The results shown vertically aligned Ni nanopillars almost covered the electrode surface, whereas the defect places are minor and insignificant in comparison with total electrode surface. We were able to not only detect urease itself but also to distinguish its native and denatured form.

Keywords: urease, electrochemical methods, nanotechnology, nanotube, nickel electrode, hanging mercury drop electrode, spectrometry

\section{Introduction}

Urease, enzyme catalyzing the hydrolysis of urea into carbon dioxide and ammonia, was firstly isolated from Cannavalia enzyformis (Fabacae) in 1926 [1]. Afterward it has been shown that urease (EC 3.5.1.5, amidohydrolases) is abundant enzyme in plants and, moreover, it can be found at numerous of eukaryotic microorganisms and bacteria [2-5]. The highest activity of urease was determined in embryonic plant tissues, first of all, in seeds of Fabaceae and Curcubitaceae species [612]. In addition, a highly active isoenzym of urease was found at developing embryos. The activity of this enzyme is very dependent on nickel presence in its active centre [13]. This enzyme is substratespecific, which means that the enzyme catalyzes the hydrolysis of urea only [14]. This feature is a basic diagnostic criterion used in the determination of many bacteria species, which produce highly active urease. Helicobacter pylori belong to such bacteria species. Many cases of peptic ulcers, gastritis, and duodenitis are caused by $H$. pylori infection. The presence of urease is therefore used in the diagnosis of Helicobacter species [15-20].

Based on these facts, analytical instruments used to rapid analysis of proteins like urease are needed. Most of the methods utilized for the detection of urease are based on analysis of its enzyme activity the hydrolysis of urea [21]. However, the direct detection of this protein is difficult. Recently, the papers reported on highly sensitive determination of proteins by means of electrochemical techniques have been published [22-32]. To construct the miniature measurement instruments the developing and suggesting of new materials for electrodes is needed. It has been shown that nano-particles have several unique physicochemical properties [33-41]. The well known and mostly used materials for nanoparticles are structures of carbon - fullerenes. Their application on suggesting and constructing of electrochemical sensors is the most advanced. One may expect that the commercial sensors and biosensors based on these nano-particles could be prepared very soon [42-67]. 
The aim of this work was to detect urease by spectrometric and voltammetric methods and to study the influence of nickel on electrochemical response of the enzyme. Moreover, the specific interaction of the protein with nickel was used in suggesting of simple sensor to detect urease.

\section{Experimental}

\subsection{Chemicals}

All analytical reagents of ACS purity were purchased from Sigma Aldrich Chemical Corp. (St. Louis, USA) unless noted otherwise. The working solutions and supporting electrolytes were prepared with ACS water (Sigma Aldrich). Deionised water for the preparation of indophenol assay underwent demineralization by reverse osmosis using the instruments Aqua Osmotic 02 (Aqua Osmotic, Tisnov, Czech Republic) and was subsequently purified using Millipore RG (Millipore Corp., USA, 18 M $\Omega$ ).

\subsection{Enzyme}

Urease EC 3.5.1.5 (Jack Beans, type III; 45000 IU/g) was purchased from Sigma Aldrich (St. Louis, USA). The stock standard solution of urease at $1 \mathrm{mg} \cdot \mathrm{ml}^{-1}$ were prepared with ACS water and stored in the dark at $-20{ }^{\circ} \mathrm{C}$. The working standard solutions were prepared daily by dilution of the stock solutions with ACS water and stored in the dark at $4{ }^{\circ} \mathrm{C}$. The basic data about urease: molecular weight 77 536, count of aminoacids 725, their sequence is as follows according to Expasy (www.expasy.ch), A - Alanine, R - Arginine, N - Asparagine, D - Aspartic Acid, C - Cysteine, E - Glutamic Acid, Q Glutamine, G - Glycine, H - Histidine, I - Isoleucine, L - Leucine, K - Lysine, M - Methionine, F Phenylalanine, P - Proline, S - Serine, T - Threonine, W - Tryptophan, Y - Tyrosine, V - Valine.

$\underline{2} \underline{2} 0 \quad \underline{30} \quad \underline{40} \quad \underline{50} \quad \underline{60}$

MNHFNRRQVL PAVPHLLNII QVEATLPNGT KLVTVHDPIA NENGDLEEAL YGSFLPVPSL

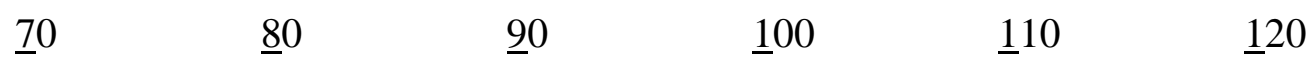

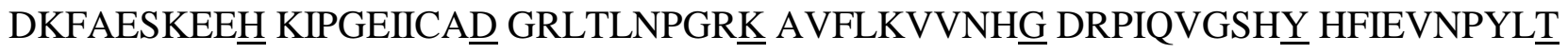

$\begin{array}{lllll}130 & 140 & 150 & 160 & 170\end{array}$

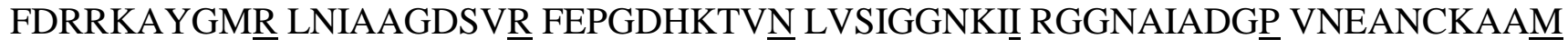
$\underline{190} \underline{200} \quad \underline{2} 10 \quad \underline{2} 20 \quad \underline{230} \quad \underline{240}$

EIVCRREFG배 KEEEEASEG므 TTGDPDCPFT KAIPREEYANㅡ KYGPTIGDKI RLGDTDLIAE

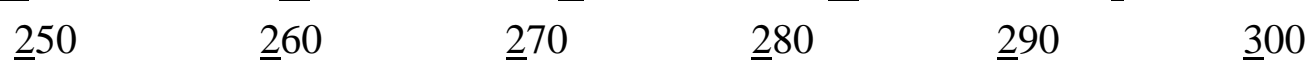

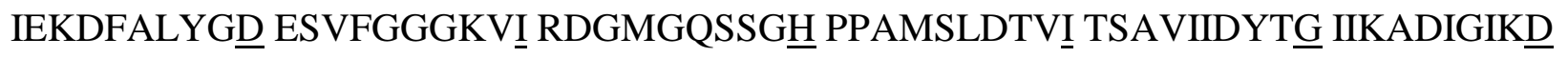

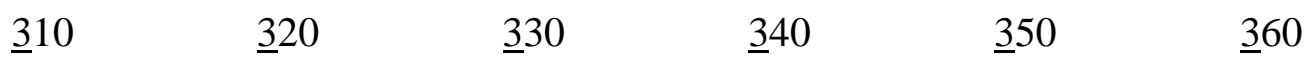

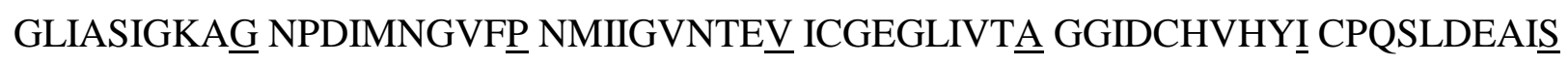

$\begin{array}{lllll}\underline{3} 70 & \underline{3} 80 & \underline{3} 90 & 400 & 410\end{array}$

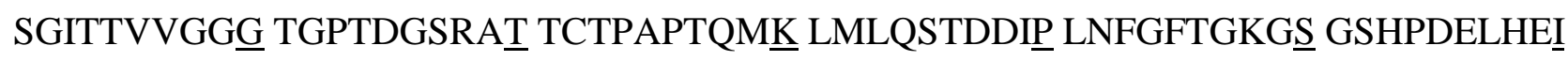

$\underline{4} 30 \quad \underline{4} 40 \quad \underline{4} 50 \quad \underline{460} \quad \underline{470} \quad \underline{480}$

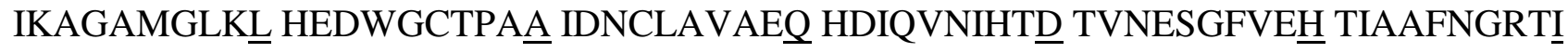

$\begin{array}{lllll}490 & \underline{5} 00 & \underline{5} 10 & \underline{5} 20 & \underline{5} 30\end{array}$

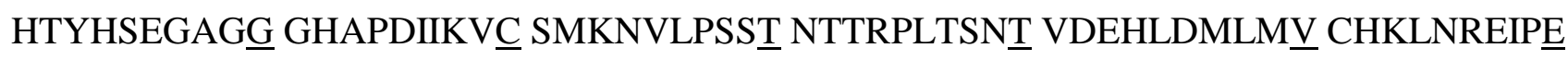


$\underline{5} 50 \quad \underline{5} 60 \quad \underline{5} 70 \quad \underline{580} \quad \underline{5} 90 \quad \underline{6} 00$

DLAFASSRVㅛㅡ EQTIAAEDIL HHIGGISIIS SDAQAVGRIG EVISCTWQT므 DKMKAERGPL $\underline{6} 10 \quad \underline{6} 20 \quad \underline{6} 30 \quad \underline{6} 40 \quad \underline{6} 50 \quad \underline{6} 60$

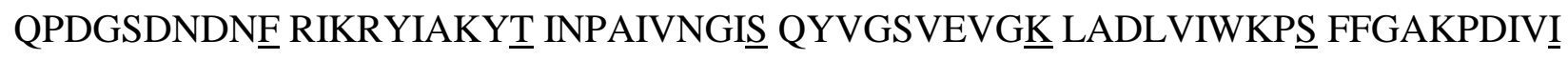
$\underline{6} 70 \underline{6} 60 \quad \underline{6} 90 \quad \underline{700} \quad \underline{710} \quad \underline{720}$

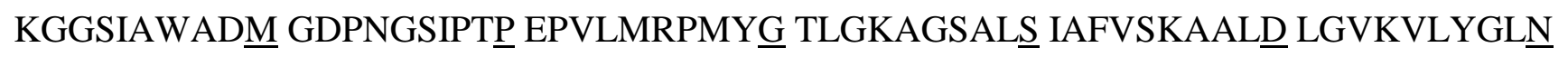
$\underline{725}$

KGWN $\underline{P}$

\subsection{Electrochemical measurements}

Electrochemical measurements were performed with AUTOLAB Analyser (EcoChemie, Netherlands) connected to VA-Stand 663 (Metrohm, Switzerland), using a standard cell with three electrodes. A hanging mercury drop electrode (HMDE) with a drop area of $0.4 \mathrm{~mm}^{2}$ was used as working electrode, an $\mathrm{Ag} / \mathrm{AgCl} / 3 \mathrm{M} \mathrm{KCl}$ electrode as reference ones and a platinum electrode as the auxiliary electrode. For smoothing and baseline correction the software GPES 4.4 supplied by EcoChemie was employed. The solutions analysed were deoxygenated by purging with argon $(99.999 \%)$ saturated with water for 120 s prior to measurements.

Adsorptive transfer stripping differential pulse voltammetric analysis of urease

Urease was measured by adsorptive transfer stripping technique (AdTS) coupled with differential pulse voltammetry (DPV). Acetate buffer (0.2 M, pH 5.0) was used as supporting electrolyte. AdTS DPV parameters were as follows: an initial potential of $-0.9 \mathrm{~V}$, an end potential $-0.3 \mathrm{~V}$, a modulation time $0.057 \mathrm{~s}$, a time interval $0.2 \mathrm{~s}$, a step potential of $1.05 \mathrm{mV}$, a modulation amplitude of $25 \mathrm{mV}, \mathrm{E}_{\mathrm{ads}}$ $=0 \mathrm{~V}$. All measurements were carried at room temperature.

\subsection{An indophenol assay for the detection of ammonium - Berthelot method}

The reagents were prepared as described in [68]. Briefly, phenolic solution - phenol (7 g) and sodium nitroprusside (disodium pentacyanonitrosylferrate, $34 \mathrm{mg}$ ) were dissolved in deionised water $(50 \mathrm{ml})$ and then made up to $100 \mathrm{ml}$. This reagent was stored in a dark-coloured bottle at $4^{\circ} \mathrm{C}$. The buffered hypochloride reagent was prepared by dissolving $2.96 \mathrm{~g} \mathrm{NaOH}$ in $140 \mathrm{ml}$ of deionised water, adding $22.29 \mathrm{~g} \mathrm{Na}_{2} \mathrm{HPO}_{4} \cdot 7 \mathrm{H}_{2} \mathrm{O}$, and dissolving it completely. Then $\mathrm{NaClO}(12 \% \mathrm{v} / \mathrm{v}, 16.6 \mathrm{ml})$ solution was added. The $\mathrm{pH}$ was adjusted to 12.0 and the deionised water was added to complete the final volume of $200 \mathrm{ml}$. This reagent was stored in a dark-coloured bottle at room temperature.

Ammonium was measured as follows: $\mathrm{NH}_{4} \mathrm{Cl}(40 \mu \mathrm{l}, 7 \mu \mathrm{g} / \mathrm{ml}-7 \mathrm{mg} / \mathrm{ml})$ was pipetted to glassy test tubes. Further, deionised water $(1960 \mu \mathrm{l})$, the phenolic solution $(200 \mu \mathrm{l})$ and the buffered hypochloride reagent $(400 \mu \mathrm{l})$ were added. The mixture was vortexed for $5 \mathrm{~min}$. using Vortex-2 Genie (Scientific Industries, New York, USA) and stored for $20 \mathrm{~min}$. at $50{ }^{\circ} \mathrm{C}$. The coloured solutions were measured by spectrophotometer (Helios, Thermo Fisher Scientific, USA) at $636 \mathrm{~nm}$ as against blank sample, which 
contains deionised water $(2 \mathrm{ml})$, the phenolic solution $(200 \mu \mathrm{l})$ and the buffered hypochloride reagent $(400 \mu 1)$. The blank sample was also stored for $20 \mathrm{~min}$. at $50{ }^{\circ} \mathrm{C}$ prior to measurements [68].

\section{5 pH measurement}

The pH value was measured using WTW inoLab Level 3 (MultiLab Pilot; Weilheim, Germany), connected to the personal computer and controlled by program (MultiLab Pilot; Weilheim, Germany). The pH-electrode (SenTix-H, pH 0-14/3M KCl) was regularly calibrated by set of WTW buffers (pH 4.01, 7.00 and 10.00) (Weilheim, Germany).

\subsection{Scanning electron microscope}

To observe electrode surfaces auto-emissive scanning electron microscope MIRA (Tescan, Brno, Czech Republic) was used. The instrument contains Schottky auto-emissive jet with high current density and three-lens optical system. The detectors used were as follows: SE Detector (secondary electron detector) and BSE Detector (backscatter electron detector). Voltage: $5 \mathrm{kV}$. The instrument was controlled by PC.

\subsection{Ni nanopillars creation}

The formation of nanostructures (nanopillars) is based on using an alumina template (Whatman Anodisc with pore diameter $100 \mathrm{~nm}$ ) with hexagonally arrayed nanopores. One of the template sides is sputtered by metal (Ni) which forms a conductive layer on the surface of the template. An area of the layer, which is not covered by $\mathrm{Al}_{2} \mathrm{O}_{3}$ (template, bottoms of the nanopores), represents a cathode in an electroplating cell. During the electroplating process under galvanostatic conditions the selected metal fills the nanopores of the template. After dissolving the template in $\mathrm{NaOH}$ or $\mathrm{H}_{3} \mathrm{PO}_{4}$ required vertically aligned nanopillars are obtained. The process is shown in Figure 1.

As an electrolyte, Watts Bath $\left(250 \mathrm{~g} / \mathrm{l} \mathrm{NiSO}_{4}, 50 \mathrm{~g} / \mathrm{l} \mathrm{NiCl}_{2}, 34 \mathrm{~g} / \mathrm{l} \mathrm{H}_{3} \mathrm{BO}_{3}\right)$ was used. The boric acid served as a buffer agent, which adjust the $\mathrm{pH}$ close to the cathodic film. The temperature of the solution was $55{ }^{\circ} \mathrm{C}$, the $\mathrm{pH}$ was usually ranging between 3 and 3.5. The current density was $15 \mathrm{~mA} / \mathrm{cm}^{2}$.

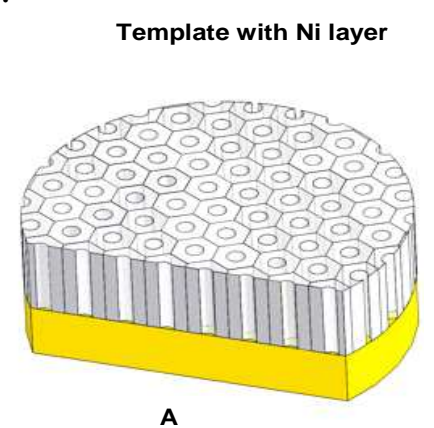

A

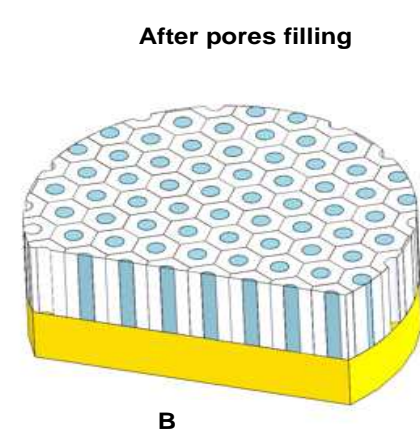

B

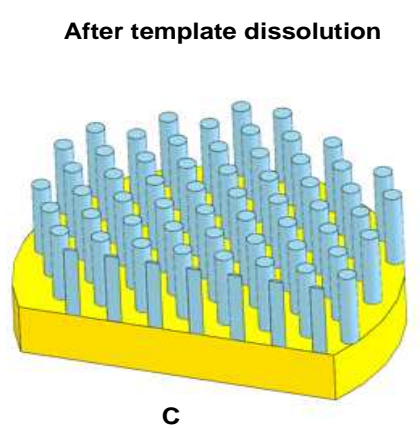

C

Figure 1. Whatman Anodisc as the template with sputtered Ni layer on the bottom (A), nanopores filled with Ni nanocrystal undergalvanostatic conditions (B), Ni nanopillars obtained after dissolution of the template $(\mathbf{C})$. 


\subsection{Ni nanoelectrode preparation for experimental measurements}

The template has been adhered to $\mathrm{Cu}$ tape with polymer conductive adhesive to avoid damage of the template and to Ni layer with nanopillar (after alumina dissolution) by manipulation during process. The $\mathrm{Cu}$ tape has been cut after the template dissolution to prepare small rectangular sheet for the electrode forming. As the Ni electrode carrier the alumina substrate has been used with screen printed conductive via isolated from surrounding and terminated by a gold pad (Figure 2). The $\mathrm{Cu}$ sheet with $\mathrm{Ni}$ nanopillars has been fixed on the gold pad using Ag epoxy glue (Aremco). Finaly the $\mathrm{Cu}$ edges have been isolated grouting by PMMA (polymethyl metacrylate).

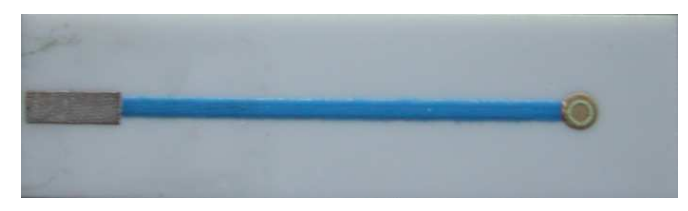

Figure 2. Thick-film electrode.

\section{Results and Discussion}

\subsection{Spectrophotometric determination of urease activity}

Most of the currently used tests aimed on determination of urease activity base in monitoring of the products of enzyme catalyzed hydrolysis of urea into carbon dioxide and ammonia (upper inset in Figure 3), where the formed ammonium interacts with a specific agent forming a coloured product. In the present paper we used the indophenol assay, in which ammonium ions reacts with $\mathrm{NaClO}$ and monochloramine is formed. Addition of the phenolic solution to monochloramine results in quinonechlorimine. The imine interacts with the phenol and indophenol occurs. In acidic solution indophenol is of yellow colour, but after alkalization of the solution the blue product is formed Berthelot reaction [68]. The resulted blue coloured solutions are shown in bottom inset in Figure 3. The intensity of the colouring strongly depends on ammonium ions concentration up to $5 \mathrm{mg} / \mathrm{ml}$, then the intensity enhances more gradually. Nevertheless laborious and time-consuming purification step must precede a utilizing of this method for analysis of real samples. Moreover, the sensitivity of detection itself is not sufficient to analyse the samples without pre-concentration steps. Therefore new methods providing simple, rapid and sensitive analysis of urease are needed. Electrochemical methods used various types of working electrodes could be considered as of these fulfilling the fore-mentioned demands. Moreover, a modification of a surface of the working electrodes by nano-materials brings new limits in their applications [52,69-76]. 


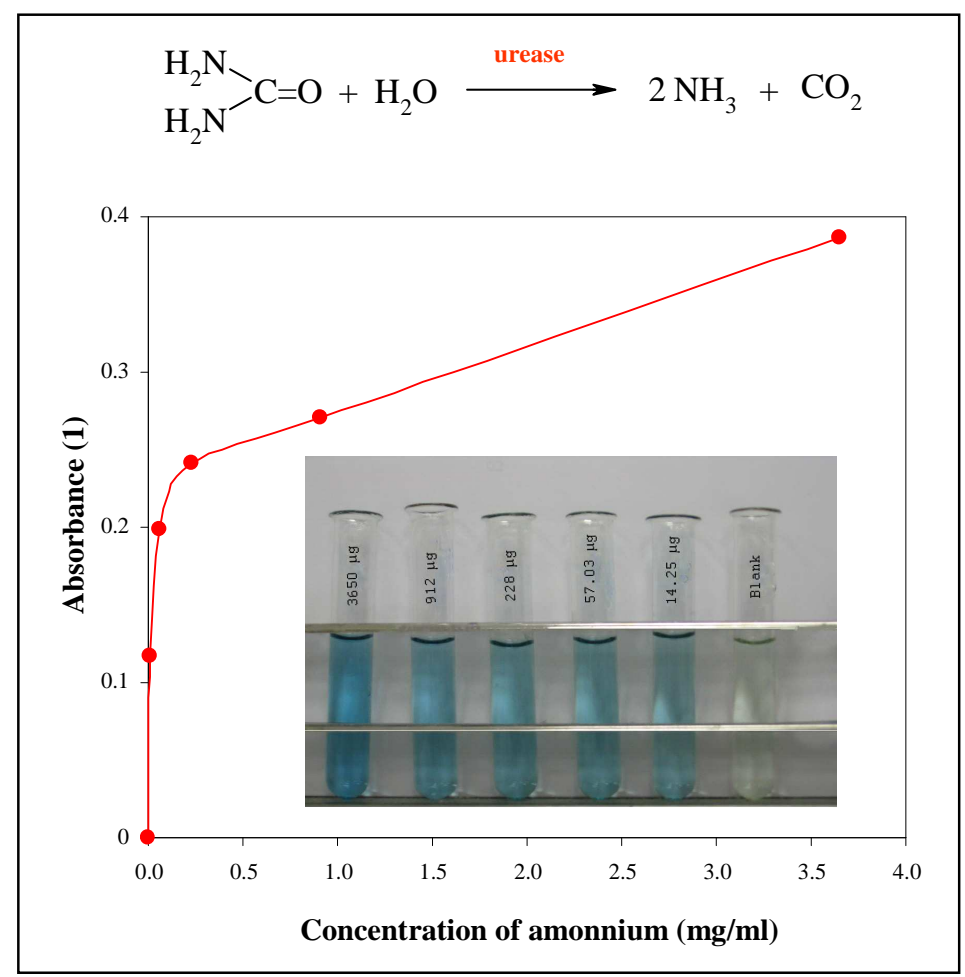

Figure 3. The scheme of the urease catalyzing hydrolysis of urea into carbon dioxide and ammonia

(upper inset). An indophenol assay for the detection of ammonium - Berthelot method. The

dependence of absorbance measured at $636 \mathrm{~nm}$ on concentration of $\mathrm{NH}_{4} \mathrm{Cl}$. The intensity of colouring of the solutions with various concentration of $\mathrm{NH}_{4} \mathrm{Cl}$ (bottom inset). The colouring of the solutions is constant for more than 60 min. For other details see in "Materials and Methods" section.

\subsection{Electrochemical study of urease}

\subsubsection{Differential pulse voltammetric analysis of urease}

To our knowledge urease has not been electrochemically studied in great details yet. The most experimental papers focus on immobilization of the enzyme on the surface of the working electrode and on detection of changes in the enzyme activity under various conditions, e.g. the presence of a toxic metal [77-80]. Here, we studied urease by means of adsorptive transfer stripping technique coupled with differential pulse voltammetry at surface of hanging mercury drop electrode. The protein was adsorbed on the surface of the working mercury electrode at open circuit; the electrode was washed in deionised water and acetate buffer. The modified electrode was transferred to the supporting electrolyte and measured in differential pulse mode. Other details on modifying of mercury electrodes by peptides and proteins can be found in the references as follows [22,25,81-91].

The basic electrochemical behaviour of urease was studied in the presence of acetate buffer $(0.2 \mathrm{M}$, $\mathrm{pH}$ 5). Typical DP voltammogram of urease $(500 \mu \mathrm{g} / \mathrm{ml})$ is shown in Figure 4A. The redox signal observed at $-0.55 \mathrm{~V}$ was well developed and reproducible. Based on our previously published papers the signal we observed can be associated with binding of the proteins (-SH groups) to mercury [30,31].

To optimize the electroanalytical detection of urease dependence of urease peak height on $\mathrm{pH}$ change of acetate buffer $(4.4-5.6)$ and phosphate buffer $(6.2-8.0)$ was studied. We found that urease gave the highest signal within $\mathrm{pH}$ range from 4.4 to 5.4. Under the higher $\mathrm{pH}$ the peak of urease 
markedly decreased and slightly shifted to negative potential of $-0.6 \mathrm{~V}$ (Figure 4B). One may except that $\mathrm{pH}$ change causes alterations of the enzyme structure, whose can result in the varying of the electrochemical response, as it was reported on electrochemical study of protein p53 [92] and lactoferrin [28]. Moreover a type of the supporting electrolyte probably influences the urease redox signal (Figure 4B).

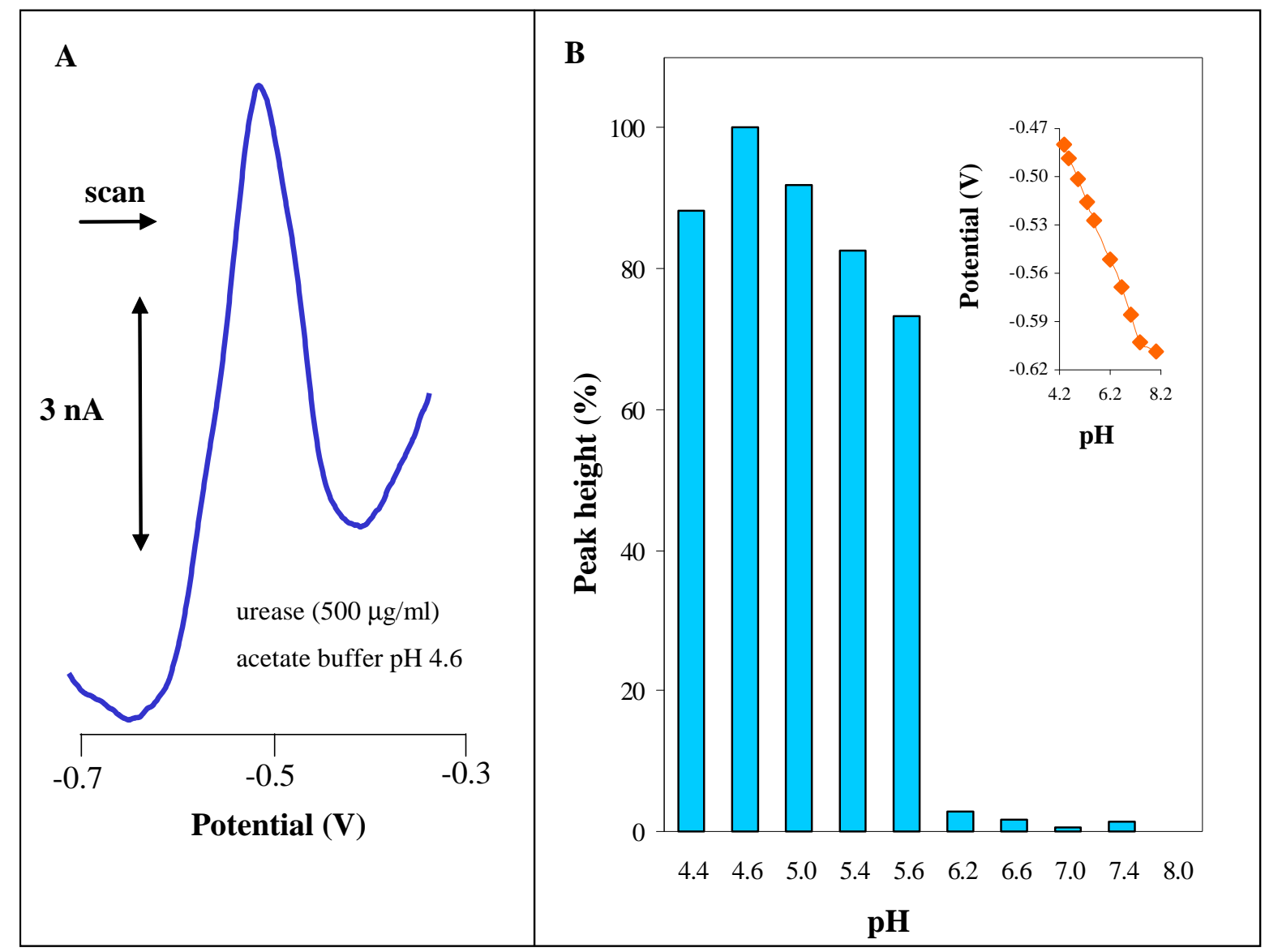

Figure 4. Differential pulse voltammogram of urease $(500 \mu \mathrm{g} / \mathrm{ml})$ measured in the presence of acetate buffer (0.2 M, pH 4.6) and accumulation time of $120 \mathrm{~s}$ (A). Changes in urease peak height in the presence of acetate ( $\mathrm{pH}$ of $4.4-5.6$ ) and phosphate buffer ( $\mathrm{pH}$ of $6.2-8.0$ ); in inset: the influence of $\mathrm{pH}$ on potential of the peak $(\mathbf{B})$.

\subsubsection{Influence of accumulation time on DPV signal of urease}

Proteins interact with a surface of a working electrode, thus, the time of the interaction belongs to the important factors influencing an analysis. The signal enhances with the increasing time interaction proportionally to full coverage of the surface. Then, multilayer of the target protein or other nonspecific interactions can occur, which result in decrease in the signal measured. Thus, we studied the influence of urease peak height on time of accumulation. We obtained well reproducible dependence. The peaks of urease were well developed and enhanced with increasing accumulation time (Figure 5A). The dependence obtained has linear trend to accumulation time of $100 \mathrm{~s}$. At accumulation times higher than $100 \mathrm{~s}$ the dependence is more gradual (Figure 5B). The potential of urease peak height 
shifted to negative ones very slightly (Figure 5B). The observed changes in the urease peak height and potential could be associated with the coverage of the working electrode surface by the protein and other non-specific interactions [30].

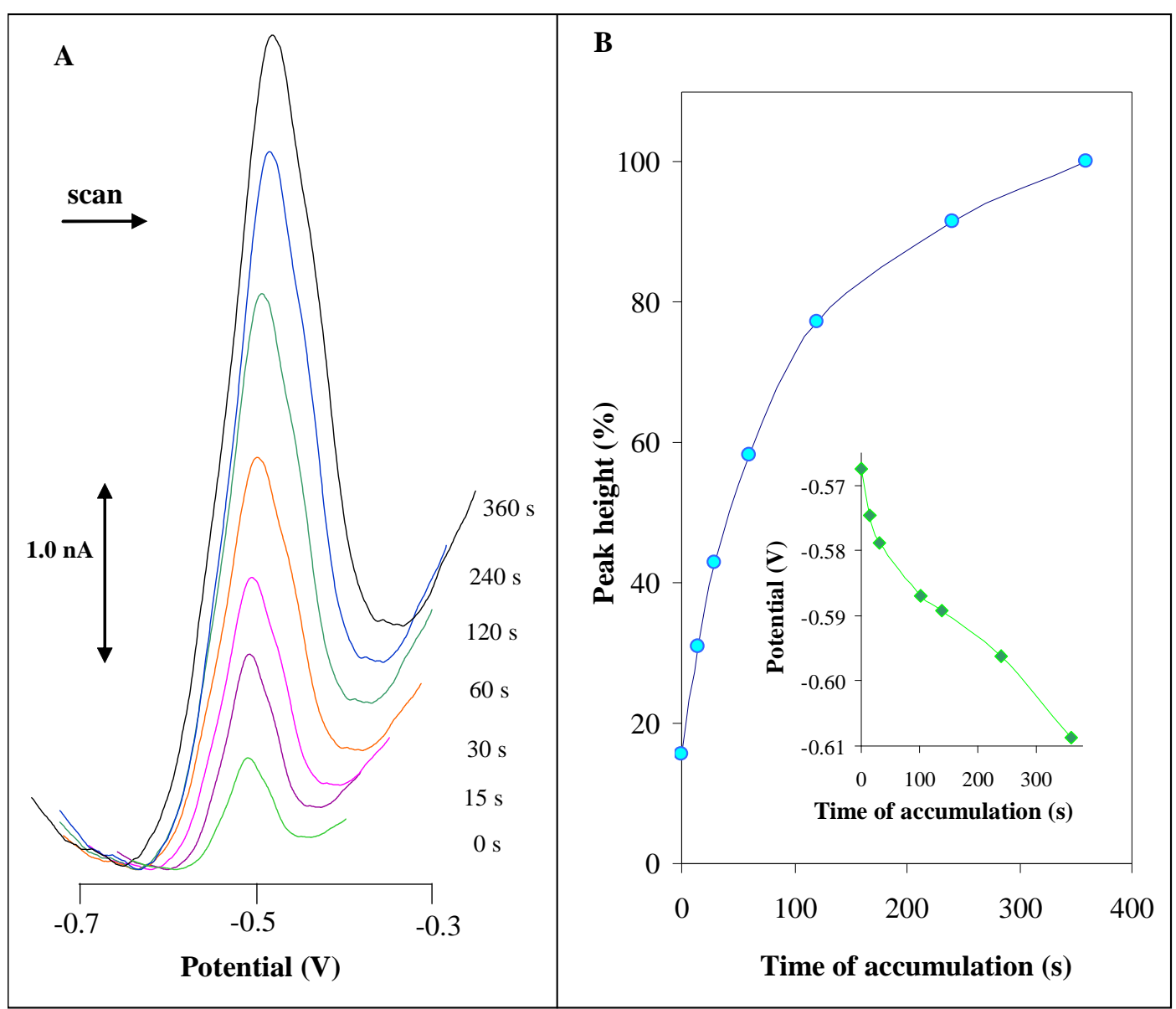

Figure 5. Typical DP voltammograms of urease $(500 \mu \mathrm{g} / \mathrm{ml})$ measured under various accumulation times (A). Dependences of urease peak height and its potential (in inset) on accumulation time (B). For other details see in Figure 4.

\subsubsection{Influence of urease concentration}

Further we were interested in the studying of urease peak height changes with increasing concentration of the protein. The higher concentration of the protein was, the higher signals were observed. The dependence obtained was not linear within the whole concentration range tested (Figure 6A). The shape of the dependence probably relates with saturation of the surface of the working electrode and with formation of multilayer coverage of the surface by the protein. However, the dependence was strictly linear within the range from 1 to $60 \mu \mathrm{g} / \mathrm{ml}$ with the equation $\mathrm{y}=0.0242 \mathrm{x}$ $0.0134, \mathrm{R}^{2}=0.9971$. Under the optimized experimental conditions $(0.2 \mathrm{M}$ acetate buffer $\mathrm{pH} 4.6$ and 
accumulation time of $120 \mathrm{~s}$ ) the detection limit of urease evaluated as $3 \mathrm{~S} / \mathrm{N}$ was $200 \mathrm{ng} / \mathrm{ml}$ with relative standard deviation below $5 \%$.

\subsection{Influence of nickel on the electrochemical signal of urease}

As we mentioned in the "Introduction" section, the activity of urease enzyme depends on the presence of nickel. Two nickel atoms are obviously bounded into urease. We were very interested in the issue how did the presence of nickel(II) ions influence the electrochemical response of urease. We kept the nickel(II) concentration constant (100 ng/ml), changed urease concentration and measured the DP voltammograms. Except the redox peak of urease we observed new signals on the voltammograms measured. These signals probably corresponds to complex of urease with nickel(II) ions. Nevertheless, we aimed our attention on the signal of urease at $-0.5 \mathrm{~V}$ only. The observed changes in this signal with increasing concentration of urease and constant concentration of nickel(II) ions are shown in Figure 6B. It can be concluded that DPV peak of urease is higher for more than $12 \%$ in the presence of nickel(II) compared to those measured without nickel(II) ions. In addition, we studied the influence of various concentration of nickel(II) ions on urease signal. We found that DPV peak of urease shifted to more negative potentials about $50 \mathrm{mV}$. Based on the results obtained the interaction of nickel(II) ions and urease can be determined using electrochemical methods. Therefore we attempted to prepare $\mathrm{Ni}$ nanoelectrodes to measure urease.

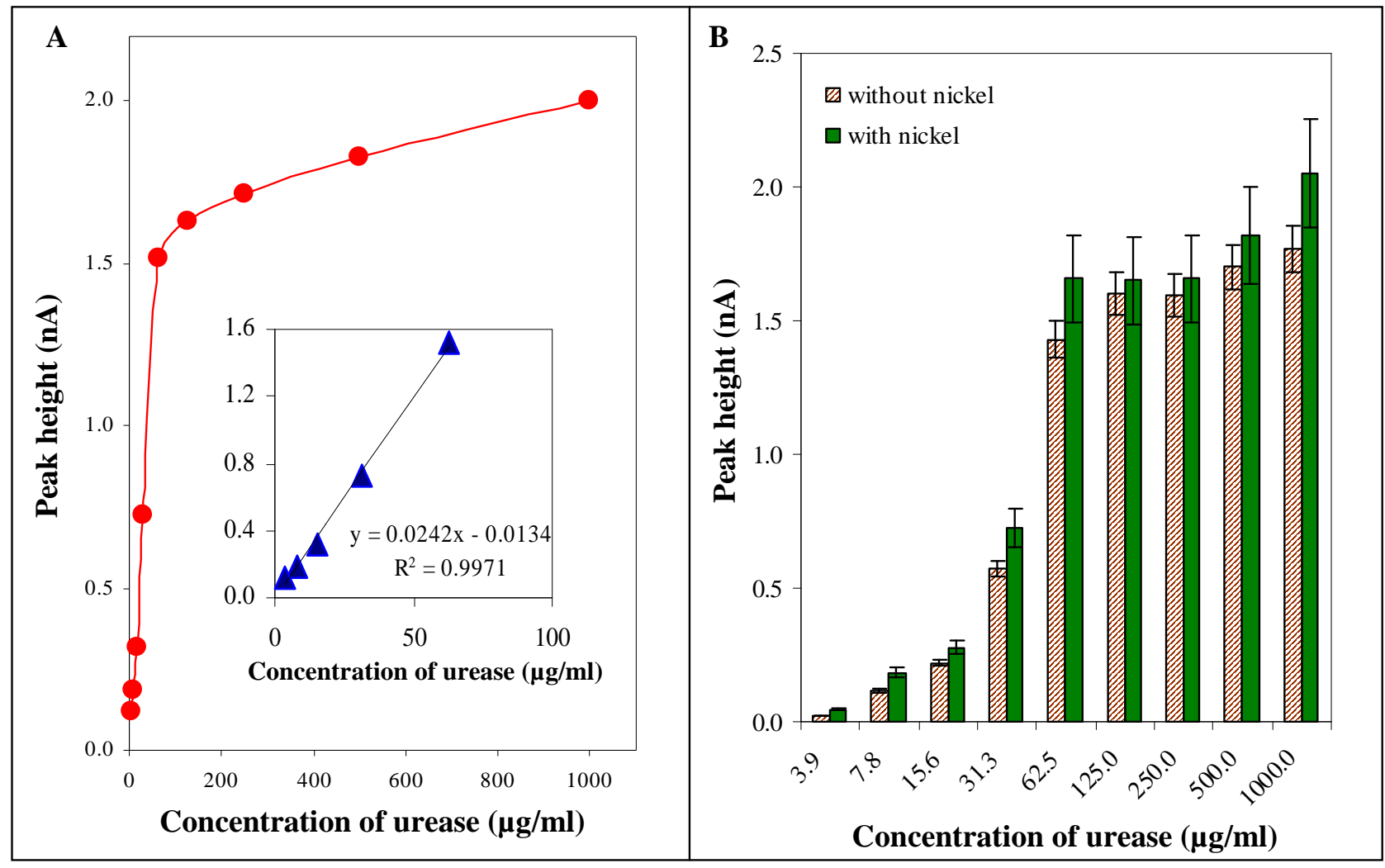

Figure 6. Dependence of urease peak height on its concentration within the range from 1 to 1,000 $\mu \mathrm{g} / \mathrm{ml}$ ) and from 1 to $60 \mu \mathrm{g} / \mathrm{ml}$ (inset) (A). The influence of nickel(II) ions on DPV urease signal (B). 


\subsection{SEM analysis of Ni nanoelectrode surface}

The Ni nanoelectrode has been analysed after the template dissolution by Scanning Electron Microscopy (SEM). The results confirm vertically aligned Ni nanopillars almost covered the electrode surface (Figure 7A). Analysis have also shown defects on the surface where Ni nanopilars are missing (Figure 7B). These defect places can be caused by impurities adhered on the template surface before electroplating or by abruption of nanopillars after the template dissolution because of their faulty bonding to Ni layer. The defect places are minor and insignificant in comparison with total electrode surface.

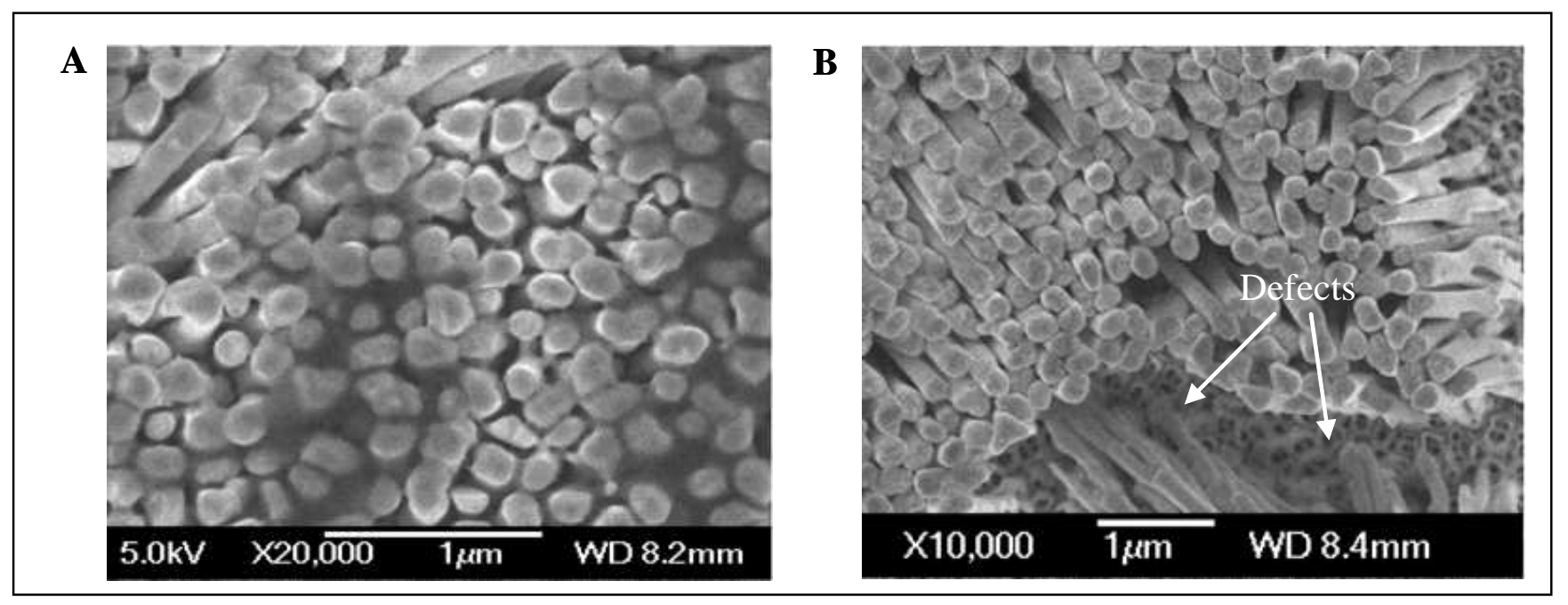

Figure 7. SEM analysis of Ni nanopillars created on the electrode, homogenously distributed Ni nanopillars (A) and detail of surface defects without Ni nanopillars (B).

\subsection{Detection of urease by Ni nanoelectrodes}

The Ni nanoelectrodes were utilized for a detection of urease. Measurements were carried out in acetate buffer $(\mathrm{pH} 4.6)$. Urease $(10 \mu \mathrm{l})$ was accumulated at the surface of Ni nanoelectrode for various times (from $30 \mathrm{~s}$ to $10 \mathrm{~min}$ ). The optimal time of accumulation was $240 \mathrm{~s}$. Under these experimental conditions urease gave oxidative signal at $0.8 \mathrm{~V}$. Previously we investigated the influence of various denaturing conditions (physical and chemical) on signals of various proteins (lactoferrin, protein p53) $[28,92]$. However, we have not utilized the stationary electrochemical instrument to measure denaturation of protein yet. Therefore we were interested in the issue whether we were able to observe a difference between signal of native and heat denatured urease. The protein was denatured for $30 \mathrm{~min}$ at $99{ }^{\circ} \mathrm{C}$. Subsequently the urease was measured at the Ni nanoelectrode. The voltammograms obtained are shown in Figure 8 (red curve - native protein, blue curve - denatured protein). Based on the results obtained the native urease gave approximately six times lower signal compared to the denatured protein. 


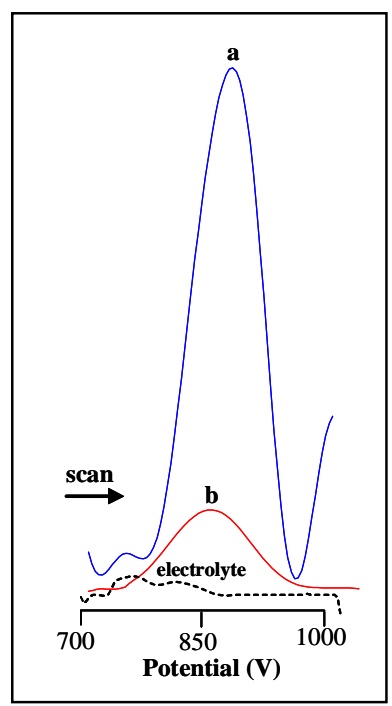

Figure 8. Square wave voltammetric analysis of urease using Ni nanoelectrode. The supporting electrolyte (acetate buffer $\mathrm{pH} 4.2$ ) - dot-and-dash black curve, a) denatured urease (30 min, $\left.99{ }^{\circ} \mathrm{C}\right)$, b) native urease. Concentration of urease $(100 \mathrm{mg} / \mathrm{ml})$. SWV parameters were as follows: frequency 200 $\mathrm{Hz}$, initial potential $-0.4 \mathrm{~V}$, end potential $1.4 \mathrm{~V}$, step potential $5 \mathrm{mV}$, amplitude $25 \mathrm{mV}$.

\section{Conclusion}

Urease belongs to group of nickel-binding proteins. In the present paper we utilized two very different analytical techniques, spectrometric and electrochemical, for detection of this protein. The spectrometric analysis is most commonly used compared to electrochemistry $[68,93]$. However we shown that the electrochemical technique is suitable not only to detect urease sensitively but also to study the interaction of urease with nickel(II) ions. Moreover, we prepared Ni nanoelectrodes and utilized it for measurement of urease. Based on the results obtained we were able to not only detect urease itself but also to distinguish its native and denatured form using Ni nanoelectrode.

\section{Acknowledgements}

This work was supported from the grant of the Grant Agency of Academy of Sciences of the Czech Republic No. GAAV IAA401990701, and GAAV 1QS201710508, and from the Czech Ministry of Education within the framework of Research Plan MSM 0021630503 and IGA MZLU 5/2007.

\section{References}

1. Sumner, J.B. The isolation and crystallization of the enzyme urease. J. Biol. Chem. 1926, 69, 435441.

2. Mobley, M.L.; Hausinger, R.P. Microbial ureases: significance, regulation and molecular characterization. Microbiol. Rev. 1989, 53, 85-108.

3. Witte, C.P.; Rosso, M.G.; Romeis, T. Identification of three urease accessory proteins that are required for urease activation in Arabidopsis. Plant Physiol. 2005, 139, 1155-1162. 
4. Witte, C.P.; Tiller, S.; Isidore, E.; Davies, H.V.; Taylor, M.A. Analysis of two alleles of the urease gene from potato: polymorphisms, expression, and extensive alternative splicing of the corresponding mRNA. J. Exp. Bot. 2005, 56, 91-99.

5. Witte, C.P.; Tiller, S.A.; Taylor, M.A.; Davies, H.V. Leaf urea metabolism in potato. Urease activity profile and patterns of recovery and distribution of N-15 after foliar urea application in wild-type and urease-antisense transgenics. Plant Physiol. 2002, 128, 1129-1136.

6. Polacco, J.C.; Winkler, R.G. Soyaben leaf urease: a seed enzyme. Plant Physiol. 1984, 74, 800803.

7. de Melo, W.J.; Aguiar, P.D.; de Melo, G.M.P.; de Melo, V.P. Nickel in a tropical soil treated with sewage sludge and cropped with maize in a long-term field study. Soil Biol. Biochem. 2007, 39, 1341-1347.

8. Thoren, A.K. Urea transformation of wetland microbial communities. Microb. Ecol. 2007, 53, 221-232.

9. Kojima, S.; Bohner, A.; von Wiren, N. Molecular mechanisms of urea transport in plants. $J$. Membr. Biol. 2006, 212, 83-91.

10. Kohler, J.; Caravaca, F.; Carrasco, L.; Roldan, A. Interactions between a plant growth-promoting rhizobacterium, an AM fungus and a phosphate-solubilising fungus in the rhizosphere of Lactuca sativa. Appl. Soil Ecol. 2007, 35, 480-487.

11. Varel, V.H.; Wells, J.E.; Miller, D.N. Combination of a urease inhibitor and a plant essential oil to control coliform bacteria, odour production and ammonia loss from cattle waste. J. Appl. Microbiol. 2007, 102, 472-477.

12. Yang, Z.X.; Liu, S.Q.; Zheng, D.W.; Feng, S.D. Effects of cadium, zinc and lead on soil enzyme activities. J. Environ. Sci. 2006, 18, 1135-1141.

13. Dixon, N.E.; Gazzola, C.; Blakeley, R.L.; Zerner, B. Jack-Bean Urease (Ec 3.5.1.5) Metalloenzyme - Simple Biological Role for Nickel. J. Am. Chem. Soc. 1975, 97, 4131-4133.

14. Zehnalek, J.; Adam, V.; Kizek, R. Assimilation of nitrate, ammonium and amide nitrogen by agricultural crops. Chem. Listy 2006, 100, 508-514.

15. Robotis, J. Two rapid urease tests comparison (CLO Vs PRONTO DRY) for the detection of HP infection. Gastroenterology 2003, 124, A176-A177.

16. Vilaichone, R.; Mahachai, V.; Nunthapisud, P.; Thong-Gyam, D.; Kullavanijaya, P. Gastric juice urease test and brushing urease test for Helicobacter pylori detection. Gut 2002, 51, A111-A112.

17. Wisniewska, M.; Nilsson, H.O.; Bak-Romaniszyn, L.; Rechcinski, T.; Bielanski, W.; PlanetaMalecka, I.; Plonka, M.; Konturek, S.; Wadstrom, T.; Rudnicka, W.; Chmiela, M. Detection of specific Helicobacter pylori DNA and antigens in stool samples in dyspeptic patients and healthy subjects. Microbiol. Immunol. 2004, 46, 657-665.

18. Xia, H.H.X.; Wong, B.C.Y. Gastric biopsy-based rapid urease tests for the detection of Helicobacter pylori: Progress, advantages and limitations. J. Gastroenterol. Hepatol. 2002, 17, 629-632.

19. Yee, Y.K.; Yip, K.T.; Que, T.L.; Chang, K.K.; Li, K.F.; Lee, C.K.; Wong, S.W.; Lau, S.F.; Szeto, M.L. Efficacy of enzyme immunoassay for the detection of Helicobacter pylori antigens in frozen stool specimens: local validation. Aliment. Pharmacol. Ther. 2002, 16, 1739-1742. 
20. Berdoz, J.; Corthesy, B. Human polymeric IgA is superior to IgG and single-chain Fv of the same monoclonal specificity to inhibit urease activity associated with Helicobacter pylori. Mol. Immunol. 2004, 41, 1013-1022.

21. Tripathi, R.N.; Nath, N.; Gandhi, A.P. Studies on the quality of canned baked soybeans. J. Food Sci. Technol.-Mysore 2004, 41, 131-134.

22. Kizek, R.; Trnková, L.; Palecek, E. Determination of metallothionein at the femtomole level by constant current stripping chronopotentiomentry. Anal. Chem. 2001, 73, 4801-4807.

23. Kizek, R.; Vacek, J.; Trnkova, L.; Klejdus, B.; Havel, L. Application of catalytic reactions on a mercury electrode for electrochemical detection of metallothioneins. Chem. Listy 2004, 98, 166173.

24. Masarik, M.; Stobiecka, A.; Kizek, R.; Jelen, F.; Pechan, Z.; Hoyer, W.; Jovin, T.M.; Subramaniam, V.; Palecek, E. Sensitive electrochemical detection of native and aggregated alphasynuclein protein involved in Parkinson's disease. Electroanalysis 2004, 16, 1172-1181.

25. Palecek, E.; Masarik, M.; Kizek, R.; Kuhlmeier, D.; Hassmann, J.; Schulein, J. Sensitive electrochemical determination of unlabeled MutS protein and detection of point mutations in DNA. Anal. Chem. 2004, 76, 5930-5936.

26. Prusa, R.; Potesil, D.; Masarik, M.; Adam, V.; Kizek, R.; Jelen, F. Fast and sensitive electrochemical detection of native, denatured, and aggregated forms of tumor suppressor protein p53. Mol. Biol. Cell 2004, 15, 249A-249A.

27. Kukacka, J.; Zitka, O.; Horna, A.; Stejskal, K.; Zehnalek, J.; Adam, V.; Havel, L.; Zeman, L.; Prusa, R.; Trnkova, L.; Kizek, R. A new tool for distinguishing of different structural forms of lactoferrin. Faseb J. 2007, 21, A635-A635.

28. Zitka, O.; Horna, A.; Stejskal, K.; Zehnalek, J.; Adam, V.; Havel, L.; Zeman, L.; Kizek, R. Study of structural changes of lactoferrin using flow injection analysis with electrochemical detection on glassy carbon electrode. Acta Chim. Slov. 2007, 54, 68-73.

29. Zitka, O.; Stejskal, K.; Kleckerova, A.; Adam, V.; Beklova, M.; Horna, A.; Supalkova, V.; Havel, L.; Kizek, R. Utilizing electrochemical techniques for detection of biological samples. Chem. Listy 2007, 101, 225-231.

30. Adam, V.; Petrlova, J.; Potesil, D.; Zehnalek, J.; Sures, B.; Trnkova, L.; Jelen, F.; Kizek, R. Study of metallothionein modified electrode surface behavior in the presence of heavy metal ionsbiosensor. Electroanalysis 2005, 17, 1649-1657.

31. Adam, V.; Zehnalek, J.; Petrlova, J.; Potesil, D.; Sures, B.; Trnkova, L.; Jelen, F.; Vitecek, J.; Kizek, R. Phytochelatin modified electrode surface as a sensitive heavy-metal ion biosensor. Sensors 2005, 5, 70-84.

32. Kizek, R.; Masarik, M.; Kramer, K.J.; Potesil, D.; Bailey, M.; Howard, J.A.; Klejdus, B.; Mikelova, R.; Adam, V.; Trnkova, L.; Jelen, F. An analysis of avidin, biotin and their interaction at attomole levels by voltammetric and chromatographic techniques. Anal. Bioanal. Chem. 2005, 381, 1167-1178.

33. Huang, X.J.; Choi, Y.K. Chemical sensors based on nanostructured materials. Sens. Actuator BChem. 2007, 122, 659-671. 
34. Daniel, S.; Rao, T.P.; Rao, K.S.; Rani, S.U.; Naidu, G.R.K.; Lee, H.Y.; Kawai, T. A review of DNA functionalized/grafted carbon nanotubes and their characterization. Sens. Actuator B-Chem. 2007, 122, 672-682.

35. Li, L.; Li, G.H.; Fang, X.S. Bi-based nanowire and nanojunction arrays: Fabrication and physical properties. J. Mater. Sci. Technol. 2007, 23, 166-181.

36. Sque, S.J.; Jones, R.; Oberg, S.; Briddon, P.R. Carbon nanotubes and their interaction with the surface of diamond. Phys. Rev. B 2007, 75, 16.

37. Billinge, S.J.L.; Levin, I. The problem with determining atomic structure at the nanoscale. Science 2007, 316, 561-565.

38. Tang, J.; Xing, G.M.; Zhao, F.; Yuan, H.; Zhao, Y.L. Modulation of structural and electronic properties of fullerene and metallofullerenes by surface chemical modifications. J. Nanosci. Nanotechnol. 2007, 7, 1085-1101.

39. Bandaru, P.R. Electrical properties and applications of carbon nanotube structures. J. Nanosci. Nanotechnol. 2007, 7, 1239-1267.

40. Chen, Y.; Lin, Y.; Liu, Y.; Doyle, J.; He, N.; Zhuang, X.D.; Bai, J.R.; Blau, W.J. Carbon nanotube-based functional materials for optical limiting. J. Nanosci. Nanotechnol. 2007, 7, 12681283.

41. Wei, W.; Sethuraman, A.; Jin, C.; Monteiro-Riviere, N.A.; Narayan, R.J. Biological properties of carbon nanotubes. J. Nanosci. Nanotechnol. 2007, 7, 1284-1297.

42. Wang, J. Carbon-nanotube based electrochemical biosensors: A review. Electroanalysis 2005, 17, 7-14.

43. Lin, Y.; Taylor, S.; Li, H.P.; Fernando, K.A.S.; Qu, L.W.; Wang, W.; Gu, L.R.; Zhou, B.; Sun, Y.P. Advances toward bioapplications of carbon nanotubes. J. Mater. Chem. 2004, 14, 527-541.

44. Martin, C.R.; Kohli, P. The emerging field of nanotube biotechnology. Nat. Rev. Drug Discov. 2003, 2, 29-37.

45. Niyogi, S.; Hamon, M.A.; Hu, H.; Zhao, B.; Bhowmik, P.; Sen, R.; Itkis, M.E.; Haddon, R.C. Chemistry of single-walled carbon nanotubes. Accounts Chem. Res. 2002, 35, 1105-1113.

46. Baughman, R.H.; Zakhidov, A.A.; de Heer, W.A. Carbon nanotubes - the route toward applications. Science 2002, 297, 787-792.

47. Thostenson, E.T.; Ren, Z.F.; Chou, T.W. Advances in the science and technology of carbon nanotubes and their composites: a review. Compos. Sci. Technol. 2001, 61, 1899-1912.

48. Terrones, M.; Hsu, W.K.; Kroto, H.W.; Walton, D.R.M. Nanotubes: A revolution in materials science and electronics, Springer-Verlag Berlin, 1999; 189-234.

49. Subramoney, S. Novel nanocarbons - Structure, properties, and potential applications. Adv. Mater. 1998, 10, 1157-+.

50. Ebbesen, T.W. Carbon Nanotubes. Annu. Rev. Mater. Sci. 1994, 24, 235-264.

51. Leoni, L.; Attiah, D.; Desai, T.A. Nanoporous platforms for cellular sensing and delivery. Sensors 2002, 2, 111-120.

52. Wang, J. Nanoparticle-based electrochemical bioassays of proteins. Electroanalysis 2007, 19, 769-776. 
53. Cochrane, C.; Koncar, V.; Lewandowski, M.; Dufour, C. Design and development of a flexible strain sensor for textile structures based on a conductive polymer composite. Sensors 2007, 7 , 473-492.

54. Jaffrezic-Renault, N.; Martelet, C.; Chevolot, Y.; Cloarec, J.P. Biosensors and bio-bar code assays based on biofunctionalized magnetic microbeads. Sensors 2007, 7, 589-614.

55. Lyons, M.E.G.; Keeley, G.P. The redox behaviour of randomly dispersed single walled carbon nanotubes both in the absence and in the presence of adsorbed glucose oxidase. Sensors $\mathbf{2 0 0 6}, 6$, 1791-1826.

56. Lu, J.H.; Cao, X.A.; Pan, C.Y.; Yang, L.F.; Lai, G.B.; Chen, J.L.; Wu, C.Q. Studies of the cataluminescence of benzene homologues on nanosized gamma-Al2O3/Eu2O3 and the development of a gas sensor for benzene homologue vapors. Sensors 2006, 6, 1827-1836.

57. Liewhiran, C.; Phanichphant, S. Influence of thickness on ethanol sensing characteristics of doctor-bladed thick film from flame-made ZnO nanoparticles. Sensors 2007, 7, 185-201.

58. De Stefano, L.; Arcari, P.; Lamberti, A.; Sanges, C.; Rotiroti, L.; Rea, I.; Rendina, I. DNA optical detection based on porous silicon technology: from biosensors to biochips. Sensors 2007, 7, 214221.

59. Liu, N.; Hui, J.; Sun, C.Q.; Dong, J.H.; Zhang, L.Z.; Xiao, H. Nanoporous zeolite thin film-based fiber intrinsic Fabry-Perot interferometric sensor for detection of dissolved organics in water. Sensors 2006, 6, 835-847.

60. Kang, B.S.; Wang, H.T.; Tien, L.C.; Ren, F.; Gila, B.P.; Norton, D.P.; Abernathy, C.R.; Lin, J.S.; Pearton, S.J. Wide bandgap semiconductor nanorod and thin film gas sensors. Sensors 2006, 6, 643-666.

61. Wang, L.Y.; Kariuki, N.N.; Schadt, M.; Mott, D.; Luo, J.; Zhong, C.J.; Shi, X.J.; Zhang, C.; Hao, W.B.; Lu, S.; Kim, N.; Wang, J.Q. Sensing arrays constructed from nanoparticle thin films and interdigitated microelectrodes. Sensors 2006, 6, 667-679.

62. Katz, E.; Willner, I. Magneto-controlled quantized electron transfer to surface-confined redox units and metal nanoparticles. Sensors 2006, 6, 420-427.

63. Zhang, X.L.; Wang, J.X.; Wang, Z.; Wang, S.C. Improvement of amperometric sensor used for determination of nitrate with polypyrrole nanowires modified electrode. Sensors 2005, 5, 580-593.

64. Bushuev, Y.; Davletbaeva, S.; Muguet, F.F. Hydration simulations of a carbon nanotube, immersed in water, according to the 3-attractor water model. Sensors 2005, 5, 139-147.

65. Yin, Y.J.; Lu, Y.F.; Wu, P.; Cai, C.X. Direct electrochemistry of redox proteins and enzymes promoted by carbon nanotubes. Sensors 2005, 5, 220-234.

66. Cheng, F.L.; Zhang, M.L.; Wang, H. Fabrication of polypyrrole nanowire and nanotube arrays. Sensors 2005, 5, 245-249.

67. Liang, W.; Yuan, Z.B. Direct electrochemistry of glucose oxidase at a gold electrode modified with single-wall carbon nanotubes. Sensors 2003, 3, 544-554.

68. Witte, C.P.; Medina-Escobar, N. In-gel detection of urease with nitroblue tetrazolium and quantification of the enzyme from different crop plants using the indophenol reaction. Anal. Biochem. 2001, 290, 102-107. 
69. Bollo, S.; Ferreyra, N.F.; Rivas, G.A. Electrooxidation of DNA at glassy carbon electrodes modified with multiwall carbon nanotubes dispersed in chitosan. Electroanalysis 2007, 19, 833840.

70. Castaneda, M.T.; Alegret, S.; Merkoci, A. Electrochemical sensing of DNA using gold nanoparticles. Electroanalysis 2007, 19, 743-753.

71. Erdem, A.; Sayar, F.; Karadeniz, H.; Guven, G.; Ozsoz, M.; Piskin, E. Development of streptavidin carrying magnetic nanoparticles and their applications in electrochemical nucleic acid sensor systems. Electroanalysis 2007, 19, 798-804.

72. Horibe, T.; Zhang, J.D.; Oyama, M. Effects of capping reagents on the electron transfer reactions on gold nanoparticle-attached indium tin oxide electrodes. Electroanalysis 2007, 19, 847-852.

73. Hsing, I.M.; Xu, Y.; Zhao, W.T. Micro- and nano-magnetic particles for applications in biosensing. Electroanalysis 2007, 19, 755-768.

74. Liu, G.D.; Wang, J.; Wu, H.; Lin, Y.Y. Nanovehicles based bioassay labels. Electroanalysis 2007, 19, 777-785.

75. Merkoci, A. Nanobiomaterials in electroanalysis. Electroanalysis 2007, 19, 739-741.

76. Rivas, G.A.; Rubianes, M.D.; Pedano, M.L.; Ferreyra, N.F.; Luque, G.L.; Rodriguez, M.C.; Miscoria, S.A. Carbon nanotubes paste electrodes. A new alternative for the development of electrochemical sensors. Electroanalysis 2007, 19, 823-831.

77. Rajesh; Bisht, V.; Takashima, W.; Kaneto, K. An amperometric urea biosensor based on covalent immobilization of urease onto an electrochemically prepared copolymer poly (N-3-aminopropyl pyrrole-co-pyrrole) film. Biomaterials 2005, 26, 3683-3690.

78. Gambhir, A.; Gerard, M.; Mulchandani, A.K.; Malhotra, B.D. Coimmobilization of urease and glutamate dehydrogenase in electrochemically prepared polypyrrole-polyvinyl sulfonate films. Appl. Biochem. Biotechnol. 2001, 96, 249-257.

79. Balugian, R.; Sorochinsky, V.; Seidguseinov, A. Electrochemical Sensor for the Determination of Urea in Blood on the Basis of Immobilized Urease. Artif. Organs 1980, 4, 137-138.

80. Karube, I.; Suzuki, S. Electrochemical Preparation of Urease-Collagen Membrane. Biochem. Biophys. Res. Commun. 1972, 47, 51-\&.

81. Palecek, E. Adsorptive transfer stripping voltammetry - determination of nanogram quanitities of DNA immobilized at the electrode surface. Anal. Biochem. 1988, 170, 421-431.

82. Palecek, E. Adsorptive transfer stripping voltammetry: Effect of electrode potential on the structure of DNA adsorbed at the mercury surface. Bioelectrochem. Bioenerg. 1992, 28, 71-83.

83. Palecek, E.; Jelen, F.; Postbieglova, I. Adsorptive transfer stripping voltammetry offers new possibilities in DNA research. Studia Biophysica 1989, 130, 51-54.

84. Palecek, E.; Postbieglova, I. Adsorptive stripping voltammetry of bimacromolecules with transfer of the adsorbed layer. J. Electroanal. Chem. 1986, 214, 359-371.

85. Adam, V.; Krizkova, S.; Zitka, O.; Trnkova, L.; Petrlova, J.; Beklova, M.; Kizek, R. Determination of apo-metallothionein using adsorptive transfer stripping technique in connection with differential pulse voltammetry. Electroanalysis 2007, 19, 339-347. 
86. Petrlova, J.; Potesil, D.; Mikelova, R.; Blastik, O.; Adam, V.; Trnkova, L.; Jelen, F.; Prusa, R.; Kukacka, J.; Kizek, R. Attomole voltammetric determination of metallothionein. Electrochim. Acta 2006, 51, 5112-5119.

87. Petrlova, J.; Potesil, D.; Zehnalek, J.; Sures, B.; Adam, V.; Trnkova, L.; Kizek, R. Cisplatin electrochemical biosensor. Electrochim. Acta 2006, 51, 5169-5173.

88. Kukacka, J.; Krizkova, S.; Zitka, O.; Prusa, R.; Adam, V.; Sures, B.; Beklova, M.; Kizek, R. Study of nucleic acids interactions with platinum based cytostatics using biosensor. Faseb J. 2007, 21, A262-A262.

89. Krizkova, S.; Adam, V.; Petrlova, J.; Zitka, O.; Stejskal, K.; Zehnalek, J.; Sures, B.; Trnkova, L.; Beklova, M.; Kizek, R. A suggestion of electrochemical biosensor for study of platinum(II)-DNA interactions. Electroanalysis 2007, 19, 331-338.

90. Adam, V.; Petrlova, J.; Potesil, D.; Lubal, P.; Zehnalek, J.; Sures, B.; Kizek, R. New electrochemical biosensor to determine platinum cytostatics to DNA structure. Chem. Listy $\mathbf{2 0 0 5}$, 99, 353-393.

91. Prusa, R.; Petrlova, J.; Kukacka, J.; Adam, V.; Sures, B.; Beklova, M.; Kizek, R. Study of interaction of glutathiones and metallothionein with cytostatics. Clin. Chem. 2006, 52, A175A175.

92. Potesil, D.; Mikelova, R.; Adam, V.; Kizek, R.; Prusa, R. Change of the protein p53 electrochemical signal according to its structural form - Quick and sensitive distinguishing of native, denatured, and aggregated form of the "guardian of the genome". Protein J. 2006, 25, 23 32.

93. Xu, Z.; Chen, X.; Qu, X.H.; Jia, J.B.; Dong, S.J. Single-wall carbon nanotube-based voltammetric sensor and biosensor. Biosens. Bioelectron. 2004, 20, 579-584.

(C) 2007 by MDPI (http://www.mdpi.org). Reproduction is permitted for noncommercial purposes. 